\title{
Hukum Pembangunan dari Mochtar Kusuma- atmadja: Mengarahkan Pembangunan atau Mengabdi pada Pembangunan?
}

\author{
M. Zulfa Aulia \\ Fakultas Hukum Universitas Jambi \\ mzulfaaulia@unja.ac.id
}

\begin{abstract}
This article discusses Hukum Pembangunan (the Law of Development), a legal thought from Mochtar Kusuma-atmadja. The concept of hukum pembangunan was backgrounded with the concern about the role of law that showed malaise in a developing society. In order for the law to have a contribution in development, the law is not sufficiently functioned to maintain the orderliness of people's lives, a conservative function, but also must be empowered to direct change and development in order. Thus the law can be a tool of social engineering. To carry out such functions, hukum pembangunan encourages the need to legal guidance which includes legal reform in the legal field that is neutral in terms of culture and religion, and legal education directed at improving technical and professional capabilities. This article shows that hukum pembangunan is a legal thought that is practically urgent in the face of increasingly complex social changes and an ongoing development agenda, and therefore will be relevant at all times. However, the unclearly criteria about what changes or developments need to be supported by law, while the character of the legal product is determined by the ongoing political constellation, causes the projection of hukum pembangunan to be easily trapped in the wills of development or power, rather than merely directing development.
\end{abstract}

Keywords: Mochtar Kusuma-atmadja; law and development; social engineering 


\section{Zulfa Aulia}

\section{Abstrak}

Artikel ini membahas hukum pembangunan, sebuah pemikiran hukum dari Mochtar Kusuma-atmadja. Konsep hukum pembangunan bermula dari keprihatinan Sang Tokoh terhadap peranan hukum yang menunjukkan kelesuan dalam masyarakat yang sedang membangun. Agar punya kontribusi dalam pembangunan, maka hukum tidak cukup difungsikan sebatas menjaga ketertiban kehidupan masyarakat, suatu fungsi yang konservatif, melainkan juga harus diberdayakan untuk mengarahkan perubahan dan pembangunan supaya berlangsung secara teratur dan tertib. Hukum dengan begitu dapat menjadi alat atau sarana dalam pembangunan. Untuk menjalankan fungsi demikian, hukum pembangunan mendorong perlu dilakukannya pembinaan hukum nasional yang meliputi antara lain pembaruan hukum pada bidang yang netral dari segi kebudayaan dan keagamaan, serta pendidikan hukum yang diarahkan pada peningkatan kemampuan teknis dan profesional. Artikel ini menunjukkan, hukum pembangunan merupakan pemikiran hukum yang secara praksis penting dalam menghadapi berbagai perubahan sosial yang semakin kompleks dan agenda pembangunan yang terus berlangsung, dan karenanya akan relevan dalam setiap masa. Namun demikian, ketidakjelasan kriteria perubahan atau pembangunan seperti apa yang perlu didukung dengan bersaranakan hukum, sementara di sisi lain karakter produk hukum itu dipengaruhi oleh konstelasi politik yang tengah berlangsung, menyebabkan proyeksi hukum pembangunan bisa dan mudah terjebak pada kehendak-kehendak pembangunan atau kekuasaan, dan bukan sekadar mengarahkan pembangunan.

Kata Kunci: Mochtar Kusuma-atmadja; hukum dan pembangunan; pembaruan masyarakat

\section{A. Pendahuluan}

Artikel ini memaparkan riwayat tokoh Mochtar Kusuma-atmadja dan mengulas pemikirannya yang dikenali sebagai hukum pembangunan. Ada dua alasan yang melatarbelakangi mengapa Mochtar Kusumaatmadja dan konsep hukum pembangunan perlu didiskusikan dalam artikel ulasan tokoh dan pemikiran hukum. Pertama, Mochtar Kusuma-atmadja merupakan tokoh hukum Indonesia dengan beragam peran yang sudah dijalani, yang relatif jarang ditemui pada tokoh hukum lainnya. Ia merupakan ilmuwan dan teknolog hukum 
yang menuangkan pemikirannya dalam berbagai tulisan terutama dalam bentuk kertas kerja sehingga bisa dibaca masyarakat secara meluas, dan juga pernah menjabat Menteri Kehakiman dan Menteri Luar Negeri pada masa pemerintahan Orde Baru. Dua peranan ini menjadikan Mochtar bisa digolongkan teknokrat hukum, yaitu teknolog yang (turut) memegang kekuasaan efektif. ${ }^{1}$ Mochtar juga tercatat pernah menjadi advokat dan diplomat, dan bahkan disebut pula sebagai budayawan. ${ }^{2}$

Kedua, dalam diskursus hukum dan ilmu hukum (di) Indonesia, konsep hukum pembangunan sesungguhnya sangat khas sebagai hak cipta Mochtar Kusuma-atmadja. Antara keduanya, Mochtar Kusuma-atmadja dan hukum pembangunan, bahkan tidak bisa dipisahkan. Sehingga patut diduga penstudi hukum di Indonesia akan selalu melekatkan nama Mochtar manakala menyebutkan hukum pembangunan. ${ }^{3}$ Sampai-sampai hal ini memunculkan istilah "mazhab Unpad"; suatu sebutan yang merujuk afiliasi tempat Mochtar mengajar dan mengembangkan konsep hukum pembangunan. ${ }^{4}$

1 Wiratmo Soekito, "Kaum Intelektual dan Teknokrat: Mencari Definisi”, Pengantar dalam Cendekiawan dan Politik, ed. Aswab Mahasin dan Ismed Natsir (Jakarta: LP3ES, cetakan kedua, 1984), hlm. xviii.

2 Hal ini terekam dalam biografi Mochtar, yang dituangkan dalam dua karya: Nina Pane, Rekam Jejak Kebangsaan Mochtar Kusuma-atmadja (Jakarta: Penerbit Buku Kompas, 2015) dan Jakob Sumardjo, "Biografi Prof. Dr. Mochtar Kusuma-atmadja, S.H., LL.M.”, dalam Mochtar Kusuma-atmadja: Pendidik \& Negarawan, ed. Mieke Komar, Etty R. Agoes, dan Eddy Damian (Bandung: Alumni, 1999).

3 Dalam artikel ulasan tokoh dan pemikiran hukum edisi perdana jurnal ini dikatakan bahwa tidak banyak sesungguhnya ilmuwan hukum Indonesia yang menghasilkan terminologi hukum yang sangat khas dan dikenali secara meluas oleh penstudi bidang ilmu hukum. Di antara yang tidak banyak itu ialah hukum progresif dari Satjipto Rahardjo dan hukum pembangunan dari Mochtar Kusuma-atmadja. Lihat M. Zulfa Aulia "Hukum Progresif dari Satjipto Rahardjo: Riwayat, Urgensi, dan Relevansi”, Undang: Jurnal Hukum, 1, 1 (2018), hlm. 161.

4 Sebenarnya patut dipertanyakan apakah betul pemikiran Mochtar ini masuk kategori mazhab tersendiri dalam diskursus ilmu hukum. Namun demikian, Lili Rasjidi ("Introduksi”) dan Togi R. Sianturi ("Apakah Ada Suatu Mazhab Unpad dalam Filsafat Hukum?”) dalam Filsafat Hukum: Mazhab dan Refleksinya, ed. Lili Rasjidi dan B. Arief Sidharta (Bandung: Remadja Karya, 1989) menyebut mulai terdengarnya ungkapan-ungkapan 
Artikel ini tentu hanya bagian kecil saja dari banyak tulisan yang sudah mendiskusikan konsep hukum pembangunan. Sebagai demikian, artikel ini membahas bagaimana urgensi dan relevansi hukum pembangunan. Sebelum sampai pada bahasan urgensi dan relevansi, terlebih dahulu dipaparkan riwayat hidup dan karya Sang Tokoh, dijelaskan apa itu hukum pembangunan beserta sejarah yang melatarbelakanginya, dan diuraikan proyeksinya dalam pembangunan hukum (di Indonesia).

\section{B. Riwayat Hidup dan Karya Mochtar Kusuma-atmadja}

Mochtar Kusuma-atamdja dilahirkan di Jakarta pada tanggal 17 Februari 1929. Ia merupakan putera sulung dari tiga bersaudara dari pasangan R. Mohammad Taslim Kusumaatmadja yang berasal dari Tasikmalaya dan Sulmini Soerawisastra dari Kuningan. ${ }^{5}$ Pada saat artikel ini ditulis, usianya sudah mencapai 89 tahun.

Mochtar mulai mengenyam pendidikan formal di Freubel School (taman kanak-kanak), dan dilanjutkan di Europeesche School (ELS), Jakarta. ELS adalah sekolah dasar kolonial Belanda yang menggunakan bahasa Belanda sebagai bahasa pengantar dengan masa pendidikan tujuh tahun, yang diperuntukkan bagi keturunan Eropa, timur asing, dan bumiputera dari tokoh terkemuka. ${ }^{6}$ Selain di ELS, Mochtar juga pernah sebentar bersekolah di Meer Uitgebreid Lager Onderwijs (MULO), Jakarta. Karena penjajahan Jepang, sistem pendidikan dasar lalu berubah menjadi Kokumin Gakko (Sekolah Rakyat), dengan lama studi enam tahun. Pendidikan lanjutannya adalah Shoto Chu Gakko (Sekolah Menengah Pertama) dan Koto Chu Gakko (Sekolah Menengah Tinggi) dengan masa belajar masing-masing tiga tahun. Sempat sekolah di SMP di Jakarta, Mochtar oleh orangtuanya dipindahkan ke Bandung dan bersekolah di SMP II. Setelah tamat, Mochtar melanjutkan ke SMT III di Cirebon dan

"mazhab Unpad".

5 Pane, Rekam Jejak Kebangsaan Mochtar, hlm. 1.

6 Dari sini tergambar Mochtar berasal dari keturunan terkemuka, padahal sebenarnya tidak. Ibunya yang meminta rekomendasi sepupu Taslim agar bisa masuk ke ELS. Pane, Rekam Jejak Kebangsaan Mochtar, hlm. 6-7. 
kemudian ke SMT Adam Bachtiar di Jakarta. ${ }^{7}$

Setelah lulus SMT pada tahun 1949, Mochtar melanjutkan pendidikan tinggi di Sekolah Lanjutan Tinggi (SLT) Ilmu dan Kebudayaan, Jakarta, yang kelak menjadi Akademi Nasional dan kemudian Universitas Nasional. Ia juga pernah belajar di Perguruan Tinggi B1 jurusan Bahasa Inggris. Di kedua tempat tersebut, Mochtar tidak belajar lama. Ia kemudian beralih ke Perguruan Tinggi Hukum (PTH) RI, salah satu dari Balai Perguruan Tinggi (BPT) RI, pada tahun 1950. PTH ini kelak melebur ke Universitas Indonesia menjadi Fakultas Hukum \& Ilmu Kemasyarakatan. Lulus pada tahun 1955, Mochtar mendapatkan gelar Meester in de Rechten (Mr.), yang kemudian diganti menjadi Sarjana Hukum (S.H.). Setelahnya, Mochtar melanjutkan kuliah di Yale University dengan beasiswa International Cooperation Administration (ICA) Amerika Serikat, dan selesai pada tahun 1956 dengan gelar Master of Law (LL.M.) dengan predikat cum laude. Sedangkan pendidikan doktor dengan gelar Doktor (Dr.) diperolehnya pada tahun 1962 di Universitas Padjadjaran. ${ }^{8}$

Mochtar memulai karirnya di Bank Indonesia pada bagian alatalat pembayaran luar negeri, dan mengajar di Universitas Padjadjaran (Unpad), Universitas Nasional (Unas), Sekolah Staf Komando Angkatan Darat (Seskoad), dan Sekolah Komando Kepolisian (Seskopol). Dalam perkembangannya, ia besar bersama Unpad, yang dimulainya pada tahun 1959. Dalam usia 32 tahun (1961), ia bahkan sudah dipercaya menjadi Dekan Fakultas Hukum. Namun karena sikapnya dalam menilai situasi negara dan masyarakat dianggap menyindir dan bertentangan dengan kebijakan penguasa, ia diberhentikan sebagai dekan dan lektor kepala pada 6 November 1962. Dengan kondisi seperti itu, pada tahun 1964 Mochtar berangkat ke Amerika Serikat untuk belajar post doctor fellowship di Harvard Law School (19641965), dilanjutkan di Law School, University of Chicagho, dan diteruskan dengan tugas riset pada Trade and Development Research Fellowship (1965-1966). Mochtar pulang ke Indonesia pada 1967 setelah

7 Pane, Rekam Jejak Kebangsaan Mochtar, hlm. 9-21; Sumardjo, "Biografi Mochtar Kusuma-atmadja”, hlm. 3-4.

8 Pane, Rekam Jejak Kebangsaan Mochtar, hlm. 21-23, 33-40, dan 69. 
situasi politik dalam negeri lebih kondusif, dan kembali mengajar di Unpad dan beberapa kampus lainnya. ${ }^{9}$

Karirnya sebagai dosen mengantarkannya menjadi guru besar dalam ilmu hukum internasional pada 1 Maret 1969. Ia juga pernah menjadi Dekan Fakultas Hukum, Pembantu Rektor I, bahkan sebagai Rektor Unpad (1973). Beberapa peran menonjol Mochtar sebagai dosen adalah menetapkan Standar Minimum Kurikulum melalui Sub-Konsorsium Ilmu Hukum (1971), memasukkan kurikulum hukum lingkungan ke dalam kurikulum Fakultas Hukum Unpad (1972), mendirikan Pendidikan Hukum Klinis Unpad (1972), dan mengubah metode pengajaran yang tidak lagi lecture system tetapi juga diskusi partisipasi aktif mahasiswa melalui case study dan legal memorandum (1990). ${ }^{10}$

Mochtar juga terlibat aktif di luar kampus. Ia beberapa kali ditunjuk mewakili Indonesia dalam forum internasional, misalnya dalam Konferensi Hukum Laut di Jenewa (21 Februari sampai dengan 27 April 1958 dan dilanjutkan kembali pada tahun 1960) dan pembahasan Konvensi Hukum Laut Internasional sampai ditandatangani pada 10 Desember 1982. Keikutsertaan dalam berbagai forum itu diawalinya dengan mengonsep Deklarasi Juanda tanggal 13 Desember 1957. Keterlibatannya dalam berbagai kegiatan di kampus maupun di luar kampus itu lalu mengantarkannya menjadi Menteri Kehakiman pada tahun 1974-1978 dan Menteri Luar Negeri pada tahun 1978-1988. Dari pengalamannya sebagai pendidik sekaligus juga teknokrat tersebut, Mochtar sebagaimana disebut Nina Pane setidaknya menghasilkan 20 buku. ${ }^{11}$

\section{Hukum Pembangunan Versi Mochtar Kusuma-atmadja}

Beberapa pertanyaan yang perlu dijawab dalam mendeskripsikan hukum pembangunan dari Mochtar Kusuma-atmadja adalah apakah hukum pembangunan itu, kapan ia bermula, dan bagaimanakah

9 Sumardjo, "Biografi Mochtar Kusuma-atmadja”, hlm. 6-9; Pane, Rekam Jejak Kebangsaan Mochtar, hlm. 69-80.

10 Sumardjo, “Biografi Mochtar Kusuma-atmadja”, hlm. 10-11.

11 Pane, Rekam Jejak Kebangsaan Mochtar, hlm. 221. 
proyeksinya dalam pembangunan hukum terutama di Indonesia. Bagian artikel ini mencoba mengulasnya.

Dalam menjawab dan membahas pertanyaan-pertanyaan tersebut, artikel ini merujuk pada lima karya pokok Mochtar, ${ }^{12}$ yaitu Fungsi dan Perkembangan Hukum dalam Pembangunan Nasional; Pembinaan Hukum dalam Rangka Pembangunan Nasional; Pembaharuan Pendidikan Hukum dan Pembinaan Profesi; Hukum, Masyarakat dan Pembinaan Hukum Nasional; serta "Pemantapan Cita Hukum dan Asas-asas Hukum Nasional di Masa Kini dan Masa yang Akan Datang”. Karya-karya tersebut merupakan makalah atau kertas kerja yang disampaikan Mochtar dalam berbagai seminar baik sebagai dosen maupun menteri. Versi publikasinya, selain yang disebut terakhir yang relatif hanya dijumpai dalam buku berupa kumpulan tulisan berjudul Konsep-konsep Hukum dalam Pembangunan, diterbitkan oleh Lembaga Penelitian Hukum dan Kriminologi Fakultas Hukum Unpad dan diedarkan oleh Penerbit Binacipta.

Dari kelima karya pokok Mochtar sebenarnya tidak dijumpai kata hukum pembangunan, kecuali hukum sebagai sarana pembangunan. ${ }^{13}$ Namun demikian, dari judul sebagian karya tersebut memang dilekatkan kata pembangunan. Mochtar sendiri belakangan dalam wawancara dengan Shidarta mengakui kesukaannya pada predikat Teori Hukum Pembangunan. ${ }^{14}$

12 Penyebutan "karya pokok" di sini dimaksudkan untuk memilah karya Mochtar yang berkaitan langsung dengan tema yang dibahas dalam artikel ini yaitu konsep hukum pembangunan. Di luar yang "pokok”, sesungguhnya Mochtar juga menulis buku lainnya, misalnya Bantuan Hukum di Indonesia Terutama dalam Hubungannya dengan Pendidikan Hukum; Pengaturan Hukum Masalah Lingkungan Hidup Manusia Beberapa Pikiran dan Saran; Konsepsi Hukum Negara Nusantara pada Konferensi Hukum Laut III; Pengantar Ilmu Hukum; serta Pengantar Hukum Internasional. Dua yang disebut terakhir merupakan buku yang ditulis bersama dengan penulis lainnya: yang pertama dengan B. Arief Sidharta dan yang kedua dengan Etty R. Agoes.

13 Lihat Mochtar Kusuma-atmadja, Hukum, Masyarakat, dan Pembinaan Hukum Nasional (Bandung: Lembaga Penelitian Hukum dan Kriminologi Fakultas Hukum Universitas Padjadjaran \& Penerbit Binacipta, 1976), hlm. 1, 9, \& 12.

14 Shidarta, "Posisi Pemikiran Teori Hukum Pembangunan dalam Konfigurasi Aliran Pemikiran Hukum (Sebuah Diagnosis Awal)", dalam Mochtar 
Dari karya pokok Mochtar diketahui, pemikiran "hukum pembangunan” bermula dari kegelisahannya tentang peranan hukum dalam kehidupan bermasyarakat dan bernegara (Indonesia). Di tengah kesibukan pembangunan, Mochtar melihat terdapat kesan hukum justru menunjukkan suatu kelesuan (malaise) atau kekurangpercayaan. Keadaan ini disebutnya tidak tepat, karena memandang rendah akan arti dan fungsi hukum dalam masyarakat. ${ }^{15}$

Mochtar lalu merefleksikan apa itu sebenarnya hukum dan bagaimana fungsinya. Menurut Sang Tokoh, hukum merupakan bagian dari kaidah sosial, tapi bukan satu-satunya. Selain oleh hukum, kehidupan manusia dalam masyarakat juga berpedoman pada kaidah moral manusia itu sendiri, agama, susila, kesopanan, dan adat-kebiasaan. Antara hukum dan kaidah-kaidah sosial lainnya itu disebutnya terdapat hubungan jalin-menjalin yang erat, yang satu memperkuat yang lainnya. ${ }^{16}$ Meski demikian, sesungguhnya ada perbedaan yang khas antara hukum dan kaidah-kaidah sosial lainnya itu, yaitu penataan ketentuan-ketentuan hukum dapat dipaksakan dengan suatu cara yang teratur. Pemaksaan yang dimaksudkan untuk menjamin penataan ketentuan-ketentuan hukum itu sendiri tunduk pada aturan-aturan tertentu, baik mengenai bentuk, cara, maupun alat pelaksanaannya. ${ }^{17}$

Oleh karena hukum memerlukan paksaan bagi penataan ketentuan-ketentuannya, maka hukum memerlukan kekuasaan bagi penegaknya. Inilah sebabnya mengapa kekuasaan disebut Mochtar menjadi unsur yang mutlak dalam suatu masyarakat hukum dalam arti masyarakat yang diatur oleh dan berdasarkan hukum. Namun begitu, kekuasaan itu sendiri mesti tunduk pada batas-batasnya yang

Kusuma-atmadja dan Teori Hukum Pembangunan: Eksistensi dan Implikasi, ed. Shidarta (Jakarta: Epistema Institut \& Huma, 2012), hlm. 9-10.

15 MochtarKusuma-atmadja, FungsidanPerkembangan HukumdalamPembangunan Nasional (Bandung: Lembaga Penelitian Hukum dan Kriminologi Fakultas Hukum Universitas Padjadjaran \& Penerbit Binacipta, tanpa tahun), hlm. 1. Meski demikian, Mochtar juga menilai, menganggap hukum memiliki "magis religious" yang dapat menyelesaikan semua persoalan sehingga dapat dicapai masyarakat yang tata tentram karta raharja, juga berlebihan.

16 Kusuma-atmadja, Fungsi dan Perkembangan Hukum, hlm. 3.

17 Kusuma-atmadja, Fungsi dan Perkembangan Hukum, hlm. 3-4. 
ditentukan oleh hukum, baik mengenai cara maupun ruang gerak atau pelaksanaannya. Hubungan timbal balik ini dapat dirupakan dengan pernyataan "hukum tanpa kekuasaan adalah angan-angan, kekuasaan tanpa hukum adalah kelaliman". ${ }^{18}$

Sebagai salah satu kaidah sosial, hukum disebut Mochtar bertujuan untuk menjaga dan mewujudkan ketertiban (order) masyarakat. Ia, ketertiban, adalah tujuan pokok dan pertama daripada segala hukum. Kebutuhan akan ketertiban ini merupakan syarat fundamental bagi adanya suatu masyarakat yang teratur. Di samping ketertiban, tujuan lain daripada hukum adalah tercapainya keadilan yang berbeda-beda isi dan ukurannya menurut masyarakat dan zamannya. ${ }^{19}$ Dengan demikian, ketertiban yang ingin diwujudkan melalui hukum itu juga harus mendekatkan pada keadilan.

Tujuan ketertiban dari hukum itu menunjukkan hukum berfungsi sebagai alat untuk memelihara ketertiban dalam masyarakat. Fungsi semacam ini disebut Mochtar sebagai fungsi konservatif, artinya bersifat memelihara dan mempertahankan yang telah tercapai. Fungsi demikian memang diperlukan dalam setiap masyarakat, termasuk masyarakat yang sedang membangun, karena di sana pun ada hasil-hasil yang harus dipelihara, dilindungi dan diamankan. Namun begitu, pada masyarakat yang sedang membangun, yang dicirikan oleh perubahan, hukum tidak cukup memiliki fungsi yang konservatif. Ia juga harus dapat membantu proses perubahan masyarakat, agar perubahan itu berlangsung secara teratur dan tertib. ${ }^{20}$

Dari uraian ini terlihat bahwa konsep hukum pembangunan dari Mochtar Kusuma-atmadja sesungguhnya ingin menjelaskan peranan atau fungsi hukum dalam masyarakat yang sedang membangun, atau di Indonesia dikenali dengan pembangunan nasional. Dalam masyarakat yang sedang membangun itu hukum hendaknya

18 Kusuma-atmadja, Fungsi dan Perkembangan Hukum, hlm. 5.

19 Kusuma-atmadja, Fungsi dan Perkembangan Hukum, hlm. 2-3.

20 Kusuma-atmadja, Fungsi dan Perkembangan Hukum, hlm. 10-12; Mochtar Kusuma-atmadja, Pembinaan Hukum dalam Rangka Pembangunan Nasional (Bandung: Lembaga Penelitian Hukum dan Kriminologi Fakultas Hukum Universitas Padjadjaran \& Penerbit Binacipta, 1975), hlm. 1; Kusuma-atmadja, Hukum, Masyarakat, dan Pembangunan Nasional, hlm. 13. 
bukan sekadar menjaga ketertiban, tetapi juga mengarahkan agar perubahan sosial dan pembangunan berlangsung dengan teratur dan tertib. $^{21}$

Sekarang, bagaimanakah proyeksi hukum pembangunan dalam pembangunan hukum terutama di Indonesia? Menurut Mochtar, perlu dilakukan "pembinaan hukum nasional", sebagaimana judul dua karyanya. Dalam upaya pembinaan hukum, Mochtar mengingatkan arti hukum secara luas yang tidak sebatas kaidah sosial sebagaimana yang sering disebutnya sebelumnya, melainkan juga meliputi keseluruhan azas-azas dalam kehidupan manusia, lembaga-lembaga (institutions) dan proses (process) yang mewujudkan berlakunya kaidah-kaidah itu dalam kenyataan. ${ }^{22}$ Karena luasnya ruang lingkup ini, maka pembinaan hukum tidak bisa dilakukan dengan pendekatan normatif saja, melainkan harus menyeluruh. ${ }^{23}$

Dalam pembinaan hukum nasional, Mochtar menekankan soal pembaruan hukum dan penyempurnaan pendidikan hukum. ${ }^{24} \mathrm{Da}-$ lam soal pembaruan hukum, pemilihan bidang hukum menjadi penting, karena ada hal-hal yang mendesak dikembangkan yang kadang-

21 Simpulan semacama ini persis uraian Mochtar, "mengatakan bahwa hukum merupakan 'sarana pembaruan masyarakat' didasarkan atas anggapan bahwa adanya keteraturan atau ketertiban dalam usaha pembangunan atau pembaruan itu merupakan suatu yang diinginkan atau bahkan dipandang (mutlak) perlu. Anggapan lain yang terkandung dalam konsepsi 'hukum sebagai sarana pembaruan' adalah bahwa hukum dalam arti kaidah atau peraturan hukum memang bisa berfungsi sebagai alat (pengatur) atau sarana pembangunan dalam arti penyalur arah kegiatan manusia ke arah yang dikehendaki oleh pembangunan atau pembaruan”. Kusuma-atmadja, Hukum, Masyarakat, dan Pembangunan Nasional, hlm. 13.

22 Arti hukum secara luas ini menurut Shidarta memiliki konsekuensi yang luas pula, karena Mochtar menggunakan kata asas, kaidah, lembaga, dan proses sekaligus dalam definisinya. Lihat Shidarta, "Posisi Pemikiran Teori Hukum Pembangunan”, hlm. 14-16.

23 Kusuma-atmadja, Pembinaan Hukum dalam Pembangunan Nasional, hlm. 11.

24 Mochtar sebenarnya menetapkan tiga kelompok masalah pokok pembinaan hukum nasional, yaitu inventarisasi dan dokumentasi hukum yang berlaku; media dan personil (unsur manusia); dan perkembangan hukum nasional. Pendidikan hukum dalam hal ini dimasukkan ke dalam bagian kelompok kedua. Lihat Kusuma-atmadja, Pembinaan Hukum dalam Pembangunan Nasional, hlm. 11-12. 
kadang tidak ada pilihan selain melakukannya, semisal penanaman modal asing. Pemilihan bidang hukum juga diperlukan karena bidang-bidang tertentu butuh perubahan secara fundamental demi pertimbangan politis, ekonomis dan sosial akibat penjajahan, misalnya hukum agraria, hukum perburuhan, hukum pertambangan, dan hukum yang berkaitan dengan industri. Dari pemilihan bidang hukum ini Sang Tokoh berpandangan perlu menangguhkan pembaruan hukum untuk bidang yang mengandung terlalu banyak halangan atau komplikasi yang bersifat kultural, keagamaan, dan sosiologis, yang disebutnya "tidak netral", sedangkan bidang hukum yang "netral" seperti hukum perseroan, hukum kontrak (perikatan), dan hukum lalu lintas, dapat diupayakan pembaruannya. ${ }^{25}$

Pandangan Mochtar yang di satu sisi mendorong perubahan dan unifikasi hukum untuk bidang yang netral dan di sisi lain membiarkan yang tidak netral tetap plural, belakangan disebutnya sebagai "membangun hukum berdasarkan wawasan nusantara", yaitu membangun hukum nasional dengan memadukan tujuan membangun hukum nasional yang satu, atau menyatukan dengan memperhatikan keanekaragaman budaya dari penduduk yang mendiami suatu negara kepulauan. Membangun hukum secara demikian berarti mengusahakan kesatuan apabila mungkin, dan membolehkan keanekaragaman bila keadaan menghendakinya, dengan tetap mengutamakan kepastian. ${ }^{26}$

Dalam soal penyempurnaan pendidikan hukum, Mochtar memandang dalam jangka panjang, pendekatan yang efektif untuk melakukan pembaruan sistem hukum suatu negara berkembang terletak dalam pembaruan pendidikan hukumnya. ${ }^{27}$ Usaha pemba-

25 Kusuma-atmadja, Hukum, Masyarakat, dan Pembangunan Nasional, hlm. 14; Kusuma-atmadja, Pembinaan Hukum dalam Pembangunan Nasional, hlm. 1213.

26 Mochtar Kusuma-atmadja, Konsep-konsep Hukum dalam Pembangunan; Kumpulan Karya Tulis, ed. Otje Salman dan Eddy Damian (Bandung: Pusat Studi Wawasan Nusantara, Hukum dan Pembangunan bekerjasama dengan Penerbit PT. Alumni, cetakan kedua, 2006), hlm. 188; Mochtar Kusumaatmadja dan Bernard Arief Sidharta, Pengantar Ilmu Hukum; Suatu Pengantar Pertama Ruang Lingkup Berlakunya Ilmu Hukum (Bandung: Alumni, cetakan keempat, 2016), hlm. 139.

27 Kusuma-atmadja, Pembinaan Hukum dalam Pembangunan Nasional, hlm. 10. 
ruan pendidikan hukum dilakukan dalam bentuk reorientasi tujuan pendidikan hukum, pelaksanaan kurikulum minimum, pembinaan tenaga pengajar, dan pendidikan hukum klinis. ${ }^{28}$ Reorioentasi terkait tujuan pendidikan perlu diupayakan agar pendidikan hukum memiliki keterhubungan dengan kebutuhan masyarakat Indonesia sebagai negara baru merdeka yang sedang berkembang, yang tidak sebatas perbaikan mutu pendidikan melainkan juga penentuan arah dan orientasi baru. Dalam kaitannya dengan kebutuhan masyarakat, maka pendidikan hukum harus diorientasikan mengarahkan hukum sebagai sarana pembangunan. ${ }^{29}$ Dalam hal kurikulum, Mochtar yang juga pernah memimpin Konsorsium Fakultas Hukum mendorong diadakannya kurikulum minimum yang harus dipenuhi suatu fakultas hukum, sehingga terjadi uniformitas kurikulum dalam batas minimum tanpa menutup kemungkinan variasi yang disesuaikan oleh tempat, keadaan, dan kemampuan; mengadakan spesialisasi tanpa meninggalkan adanya suatu pendidikan dasar yang bersifat umum; dan membuka kemungkinan penggunaan pendekatan multi dan interdisipliner sebagai matakuliah pilihan. ${ }^{30}$

28 Dalam catatan Mardjono Reksodiputro, Mochtar juga sempat mengusulkan dalam Konsorsium Ilmu Hukum untuk menghilangkan skripsi dalam pendidikan hukum, yang ditujukan agar pendidikan hukum lebih mengarah pada legal skills training. Tapi usul ini ini tidak diterima, dan sebagai komprominya, berdasarkan usulan Mardjono, penulisan hukum dalam pendidikan hukum dapat berupa skripsi atau legal memorandum(suatu analisis langsung secara ilmiah dari suatu permasalahan hukum yang telah diteliti mahasiswa yang bersangkutan). Lihat: Mardjono Reksodiputro, "Mochtar Kusumaatmadja Sebagai Pemikir dan Penggagas Modernisasi Pendidikan Hukum di Indonesia”, dalam Mochtar Kusuma-atmadja: Pendidik \& Negarawan, ed. Mieke Komar, Etty R. Agoes, dan Eddy Damian (Bandung: Alumni, 1999), hlm. 717.

29 Mochtar Kusuma-atmadja, Pembaharuan Pendidikan Hukum dan Pembinaan Profesi (Bandung: Lembaga Penelitian Hukum dan Kriminologi Fakultas Hukum Universitas Padjadjaran \& Penerbit Binacipta, 1975), hlm. 11-12.

30 Mochtar Kusuma-atmadja, Pembaharuan Pendidikan Hukum, hlm. 8. Menurut Soetandyo Wignjosoebroto ("Mochtar Kusuma-atmadja: Manusia yang Pernah Saya Kenal dan Pemikirannya [Sebuah Pengantar Ringkas]", Mochtar Kusuma-atmadja dan Teori Hukum Pembangunan: Eksistensi dan Implikasi, ed. Shidarta [Jakarta: Epistema Institut \& Huma, 2012], hlm. xii-xiii), ada dua kebijakan dasar pengajaran dan pendidikan hukum atau ilmu hukum yang dalam perkembangannya difungsikan sebagai arahan. 
Mochtar juga mendorong diadakannya pendidikan klinis hukum, yang dimaksudkan untuk membekali mahasiswa dengan keterampilan teknik hukum yang dibutuhkan seorang ahli hukum di masyarakat. Pendidikan klinis ini diberikan dalam bidang peradilan dan perancangan (drafting), yang ditujukan untuk mempersiapkan mahasiswa sebagai pengacara, penuntut umum, dan hakim, serta mahir merancang kontrak maupun peraturan perundang-undangan. Dengan demikian terlihat pendidikan klinis hukum merupakan bagian dari upaya "profesionalisasi" pendidikan hukum, yang sebelumnya lebih cenderung sebagai pendidikan akademis. ${ }^{31}$

Sampai di sini terlihat bahwa konsep hukum pembangunan versi Mochtar Kusuma-atmadja dimaksudkan untuk lebih memberdayakan fungsi hukum dalam masyarakat yang tengah membangun. Dalam mendukung pembangunan (nasional), hukum pembangunan tidak saja berhenti pada penjelasan apa itu hukum dan fungsinya, tetapi juga sampai pada tahap bagaimana proyeksinya. Proyeksi itu juga tidak sebatas pada pemilihan bidang hukum seperti apa yang sebaiknya dilakukan pembaruan, melainkan pula penyiapan sumber daya yang menjalankannya. ${ }^{32}$

\section{Urgensi dan Relevansi Pemikiran Hukum Pembangunan}

Bagian ini membahas urgensi pemikiran hukum pembangunan dan relevansinya saat ini. Dalam membahas soal urgensi dan relevansi ini,

Pertama, pengajaran dan pendidikan hukum mestilah ditujukan untuk memajukan kedayagunaan hukum untuk kepentingan kerja-kerja praktis sehari-hari kaum profesional; kedua, secara teoretis dan politis, hukum harus bisa didayagunakan untuk kepentingan pembangunan. Sejak saat itu, kurikulum pendidikan hukum terisi oleh ajaran teori law as a tool of social engineering dalam kerangka fungsinya sebagai kontrol teknokratik demi suksesnya pembangunan.

31 Kusuma-atmadja, Pembaharuan Pendidikan Hukum, hlm. 15-16.

32 Artikel ini tidak sampai pada pembahasan fase kedua teori hukum pembangunan (Lili Rasjidi, "Fase Kedua Perjalanan Teori Hukum Pembangunan", dalam Mochtar Kusuma-atmadja dan Teori Hukum Pembangunan: Eksistensi dan Implikasi, ed. Shidarta [Jakarta: Epistema Institut \& Huma, 2012], hlm. 121-131), karena bahan-bahan mengenainya (jika ada) tidak terpublikasi, atau setidaknya tidak diperoleh pada saat artikel ini ditulis. 


\section{Zulfa Aulia}

artikel ini menelaahnya dari sudut akademis dan praksis. Sudut akademis di sini dimaksudkan sebagai perspektif yang menelaah hukum pembangunan dalam pemikiran hukum; sedangkan sudut praksis merupakan perspektif yang menelaahnya dalam praktik hukum.

Dari sudut akademis perlu dibahas bagaimana sebenarnya kedudukan hukum pembangunan dalam jagat pemikiran hukum yang dikenali selama ini. Shidarta dalam hal ini telah secara baik membahasnya dalam "Posisi Pemikiran Teori Hukum Pembangunan dalam Konfigurasi Aliran Pemikiran Hukum (Sebuah Diagnosis Awal)". Mochtar sendiri dalam berbagai karya pokoknya juga menyinggung kemiripan atau kedekatan konsep hukum yang dikembangkannya dengan konsepsi law as a tool of social engineering, yang umum diketahui sebagai proyeksi aliran sociological jurisprudence. ${ }^{33}$ Mochtar juga sempat menyebut aliran legisme, positivisme hukum, mazhab sejarah, dan realisme hukum ketika menjelaskan hukum pembangunan, namun ini dilakukan dengan sekadarnya saja. ${ }^{34}$ Sudut akademis di sini akan menelusuri keterkaitan hukum pembangunan dengan aliran-aliran pemikiran yang disebut oleh Mochtar.

Legisme, aliran pemikiran pertama yang disebut Mochtar, pada dasarnya adalah sebuah gerakan isme hukum yang mengasumsikan setiap kegiatan penerapan hukum itu semata-mata hanyalah suatu penerapan isi dari undang-undang terhadap perkara konkret. Penerapan ini dilaksanakan secara rasional dan logis. Hal ini disebabkan undang-undang merupakan suatu sistem yang logis, yang bisa diberlakukan terhadap setiap perkara. ${ }^{35}$ Dengan begitu, legisme itu terkait dengan legalitas, yaitu suatu keadaan di mana undang-undang merupakan satu-satunya sumber yang menentukan pidana bagi setiap delik, dan hak untuk membuat undang-undang hanya ada pada

33 Kusuma-atmadja, Hukum, Masyarakat, dan Pembangunan Nasional, hlm. 5-9; 25. Mochtar sendiri dalam kaitan dengan konsep law as a tool of sociological engineering ini malah menyebutnya sebagai bagian dari aliran pragmatic legal realism.

34 Kusuma-atmadja, Hukum, Masyarakat, dan Pembangunan Nasional, hlm. 3-10.

35 E. Fernando M. Manullang, Legisme, Legalitas dan Kepastian Hukum (Jakarta: Kencana, 2016), hlm. 14. 
pembuat undang-undang. ${ }^{36}$

E. Fernando M. Manullang dengan mengutip L.J. van Apeldoorn menjelaskan, legalitas bermula dari pemikiran J.J. Rousseau tentang proses pembentukan hukum. Menurut Rousseau, undang-undang adalah pernyataan kehendak yang orisinal dari rakyat, dan itu menjadi sumber satu-satunya bagi pembentukan hukum. Akibatnya, kebiasaan-kebiasaan dalam masyarakat menjadi sumber hukum yang tidak diakui secara formal, yang oleh van Apeldoorn disebut sebagai "undang-undang secara diam-diam”. Proses pembentukan hukum (undang-undang) itu merupakan kewenangan istimewa pembentuk undang-undang, sehingga tidak ada tempat bagi kebiasaan yang hidup di masyarakat sebagai dasar pembentukan hukum. ${ }^{37}$

Keterkaitan legisme dengan hukum pembangunan, dengan begitu terletak pada kesamaannya yang menempatkan hukum tertulis berupa undang-undang sebagai sumber penting dalam berhukum. Pandangan Mochtar yang menilai penting undang-undang terlihat dalam berbagai kertas kerjanya, antara lain mengatakan "di Indonesia di mana undang-undang merupakan cara pengaturan hukum yang utama, pembaruan masyarakat dengan jalan hukum berarti pembaruan hukum terutama melalui perundang-undangan". ${ }^{38} \mathrm{Pe}-$ nilaian penting terhadap hukum tertulis dalam hukum pembangunan ini mudah dipahami: jika menghendaki hukum menjadi sarana pembaruan masyarakat atau sarana pembangunan, tentu saja yang disebut hukum dan dijadikan yang utama itu harus tertulis; dan sebaliknya, meletakkan hukum tidak tertulis (living law) sebagai hukum yang utama, jelas sangat sulit diterima kalau tidak malah menghambat upaya mengikuti kehendak-kehendak pembaruan atau pembangunan.

Meski memiliki kedekatan, antara legisme dan hukum pembangunan juga terdapat perbedaan. Perbedaan itu terletak pada soal penempatan hukum kebiasaan yang hidup di masyarakat, yang dalam legisme tidak diberi tempat. Sedangkan pada hukum pembangunan,

36 Manullang, Legisme, Legalitas dan Kepastian Hukum, hlm. 11.

37 Manullang, Legisme, Legalitas dan Kepastian Hukum, hlm. 9.

38 Kusuma-atmadja, Hukum, Masyarakat, dan Pembangunan Nasional, hlm. 14. 
sekalipun tetap memprioritaskan hukum berupa undang-undang dan berlaku secara universal dalam satu wilayah hukum (nasional), sesungguhnya masih diberi tempat keberlakuan hukum kebiasaan, yaitu untuk bidang-bidang yang sangat kuat keterkaitannya dengan aspek budaya, keagamaan, dan sistem sosial masyarakat, atau disebut Mochtar dengan bidang hukum "yang tidak netral”. Inilah sebabnya mengapa dalam persoalan perkawinan dan kewarisan, dibiarkan tetap berlaku secara plural, karena memang upaya unifikasi pada bidang hukum tersebut akan menemui banyak hambatan. ${ }^{39}$

Aliran hukum sejarah atau mazhab hukum historis (historical school jurisprudence), aliran berikutnya yang disinggung Mochtar, merupakan aliran hukum yang dikembangkan Friedrich Karl von Savigny pada paruh pertama abad ke-19. Aliran ini mendalilkan hukum sebagai bagian dari sejarah; hukum merupakan nilai yang berakar dari jiwa suatu bangsa (volksgeist). Aliran hukum sejarah berpandangan hukum itu tumbuh dan berkembang dalam jiwa bangsa, tidak dibuat dan apalagi secara sengaja. Hukum terbentuk melalui mekanisme bottom up (dari bawah ke atas), tidak top down (atas ke bawah). ${ }^{40}$

Oleh karena hukum merupakan pernyataan jiwa bangsa, maka apa yang menjadi kaidah hukum akan berbeda-beda antara bangsa yang satu dengan lainnya. Pandangan semacam ini dengan mudah menunjukkan keberbedaan aliran hukum sejarah dengan hukum

39 Pada bidang perkawinan sebenarnya berlangsung "pluralisme hukum secara terbatas", sedangkan pada soal kewarisan memang plural sepenuhnya.

40 Atip Latipulhayat, "Friedrich Karl von Savigny", Padjadjaran: Jurnal Ilmu Hukum, 2, 1 (2015), hlm. 197-198. Dalam buku yang ditulis Theo Huijbers disebutkan, hukum dalam pandangan von Savigny adalah ciptaan manusia bebas, tapi manusia bebas itu bukan manusia individual. Bagi von Savigny tidak ada individu-individu, yang ada adalah manusia sebagai bagian dari suatu kesatuan yang lebih tinggi, yakni keluarga, bangsa, dan negara. Kehidupan kesatuan yang lebih tinggi itu sendiri dalam setiap masanya selalu terjalin dengan masa sebelumnya, sehingga kebudayaan dan hukum hanya dapat berasal dari jiwa bangsa, oleh karena bangsa itu tetap memegang hubungannya dengan masa yang lampau. Dengan begitu, hukum sesungguhnya tidak berasal dari individu, melainkan dari jiwa bangsa yang erat terjalin dengan sejarah. Theo Huijbers, Filsafat Hukum dalam Lintasan Sejarah (Yogyakarta: Penerbit Kanisius, 1982), hlm. 118-119. 
pembangunan, sebab hukum pembangunan justru mengutamakan hukum tertulis yang berlaku universal, yang umumnya terbentuk dari kehendak penguasa. Dalam hukum pembangunan juga dimungkinkan untuk menggunakan model hukum asing sepanjang sesuai dengan kebijakan pembangunan, yang dengan demikian bisa jadi tidak ada akar sejarahnya di negara importir.

Kalaupun ada keterkaitan dengan hukum sejarah, keterkaitan itu hanya soal pandangan Mochtar bahwa hukum sebagai kaidah sosial tidak bisa dilepaskan dari nilai (values) yang berlaku di suatu masyarakat. Mochtar juga menyebut, hukum merupakan pencerminan dari nilai-nilai yang berlaku dalam masyarakat, sehingga hukum yang baik adalah yang sesuai dengan hukum yang hidup dalam masyarakat (the living law). ${ }^{41}$ Namun demikian, pernyataan semacam ini bisa jadi kontradiktif, mengingat pada sisi utamanya hukum pembangunan justru memberikan ruang kepada negara untuk menentukan hukum seperti apa yang dibentuk dan berlaku, dan bahkan membuka ruang bagi adopsi hukum asing sepanjang mendukung kehendak-kehendak pembangunan, dan karenanya terbuka kemungkinan adanya pertentangan dengan hukum yang hidup.

Aliran realisme hukum, ${ }^{42}$ yang juga disinggung oleh Mochtar, merupakan aliran hukum yang berinduk pada empirisme, yaitu pengetahuan yang bertumpu pada kenyataan empiris. Empirisme menolak pengetahuan spekulatif yang hanya mengandalkan penalaran logis ala rasionalisme. Ide-ide rasional dalam empirisme tidak bisa diandalkan sebagai sumber kebenaran tunggal, melainkan perlu dipastikan kebenarannya dalam dunia empiris. ${ }^{43}$

41 Kusuma-atmadja, Fungsi dan Perkembangan Hukum, hlm. 8.

42 Soetandyo Wignjosoebroto (Pergeseran Paradigma dalam Kajian-kajian Sosial dan Hukum [Malang: Setara Press, 2013], hlm. 128-129) dengan menyetujui pandangan Milovanovic mengatakan realisme hukum (legal realism, the realisticjurisprudence) lebih merupakan gerakan sosial menuju ke pembaruan hukum daripada suatu rintisan baru yang menghasilkan mazhab baru. Sebagai sebuah gerakan, realisme hukum sesungguhnya meneruskan apa yang dirintis oleh Roscoe Poun dengan sociological jurisprudence-nya.

43 Bernard L. Tanya, Yoan N. Simanjuntak, dan Markus Y. Hage, Teori Hukum: Strategi Tertib Manusia Lintas Ruang dan Generasi (Yogyakarta: Genta Publishing, cetakan keempat, 2013), hlm. 149. 


\section{Zulfa Aulia}

Realisme hukum, yang dikembangkan oleh Holmes, memandang aturan hukum tidak bisa diandalkan menjawab dunia kehidupan yang begitu kompleks, karena hukum yang termuat dalam aturanaturan hanya suatu generalisasi mengenai dunia ideal. Tidak jarang kebenaran-kebenaran lain di luar aturan formal lebih relevan, tepat, dan bahkan bermanfaat untuk konteks riil. Oleh karena itu hakim mempunyai peranan yang penting dalam menentukan mana hukum yang relevan, tepat, dan bermanfaat itu. Bagi Holmes, aturan-aturan hukum hanya menjadi salah satu faktor yang patut dipertimbangkan dalam keputusan yang "berbobot". Selebihnya, faktor moral, soal kemanfaatan, dan keutamaan kepentingan sosial misalnya, menjadi faktor yang tidak kalah penting dalam mengambil keputusan yang berbobot itu. ${ }^{44}$

Dalam kaitannya dengan realisme hukum, maka keterhubungan hukum pembangunan terlihat hanya pada soal fungsi hukum, bahwa hukum harus lebih mengutamakan kemanfaatan dan kepentingan sosial. Selebihnya, soal siapa yang berperan dan bagaimana peranan dalam mewujudkan hukum yang lebih mengutamakan kemanfaatan dan kepentingan sosial, jelas sekali berbeda. Jika pada realisme hukum yang berperan adalah hakim sebagai yang lebih mengetahui realitas dan dijalankan melalui proses yudikasi, maka dalam hukum pembangunan peran itu dijalankan oleh pembentuk undang-undang melalui proses legislasi. Produk legislasi itu dalam realisme hukum justru menjadi pusat kritik, sehingga dalam berhukum bisa saja keluar darinya sepanjang mendorong pada kemanfaatan dan kepentingan sosial.

Aliran hukum berikutnya yaitu sociological jurisprudence, yang disebut Mochtar mengilhami hukum pembangunan, merupakan aliran hukum yang dikembangkan oleh Roscoe Pound. Ia bermula dari suatu kesadaran bahwa struktur suatu masyarakat itu selalu berada dalam ketimpangan: ada yang terlalu dominan dan ada yang terpinggirkan. Untuk menciptakan keseimbangan, dunia yang beradab, maka ketimpangan-ketimpangan struktural itu perlu ditata ulang.

44 Tanya, Simanjuntak, dan Hage, Teori Hukum, hlm. 149-151. 
Bagi Pound, hukum yang bersifat logis-analitis dan serba abstrak (hukum murni) ataupun yang berisi gambaran realitas apa adanya (sosiologis), tidak mungkin diandalkan. Langkah progresif yang harus dilakukan ialah dengan memfungsikan hukum untuk menata perubahan, sehingga muncullah konsep law as a tool of social engineering. Kepentingan-kepentingan yang ada dalam masyarakat harus ditata kembali, agar tercapai keseimbangan yang proporsional. ${ }^{45}$

Hukum sebagai sarana social engineering bermakna penggunaan hukum secara sadar untuk mencapai suatu tertib atau keadaan masyarakat sebagaimana dicita-citakan, atau untuk melakukan perubahan-perubahan yang diinginkan. ${ }^{46}$ Hukum dengan begitu tidak lagi menjadi kaidah yang berfungsi konservasif menjaga ketertiban masyarakat, melainkan juga kaidah yang dapat diberdayakan untuk mencapai tujuan-tujuan tertentu dalam sauatu masyarakat. Dalam rangka memfungsikan hukum secara demikian, Pound berpendapat hakim harus diberi ruang cukup luas dalam setiap penyelesaian kasus untuk menetapkan apa yang adil dan apa yang kurang adil dalam setiap penciptaan amar putusan hukum. Aturan-aturan hukum harus dipandang sebagai pedoman dan pengarah saja, dan selebihnya hakim yang lebih memahami karakterisitik kasus untuk diambil putusan yang berpengaruh positif pada kehidupan orang-orang dalam masyarakat. ${ }^{47}$

Dalam kaitannya dengan sociological jurisprudence, hukum pembangunan terlihat memiliki keterhubungan dan kedekatan dalam hal memfungsikan hukum, bahwa hukum tidak sekadar berfungsi konservasi menjaga status quo, melainkan juga mendukung perubahan atau pembangunan yang tengah berlangsung. Hukum dengan demikian merupakan instrumen dalam perubahan sosial atau pembangunan. Namun demikian, keduanya juga sebenarnya berbeda dalam hal aktor yang menjalankan fungsi tersebut dan si-

45 Tanya, Simanjuntak, dan Hage, Teori Hukum, hlm. 139-140.

46 Satjipto Rahardjo, Hukum dan Perubahan Sosial (Yogyakarta: Genta Publishing, 2009), hlm. 128-129.

47 Wignjosoebroto, Pergeseran Paradigma Kajian Sosial dan Hukum, hlm. 126127. 
fat perubahan yang dimaksud. Pada sociological jurisprudence, karena berkembang di Amerika yang termasuk dalam keluarga hukum common law, maka aktor hukum dalam perubahan sosial itu dijalankan oleh hakim melalui putusan-putusannya. Proses yudisial, dengan begitu akan menentukan perubahan sosial yang dikehendaki seperti apa. Pada hukum pembangunan justru sebaliknya, karena mewarisi tradisi hukum kolonial yang termasuk dalam keluarga civil law, maka aktor hukum dalam perubahan sosial dijalankan oleh pembentuk undang-undang melalui proses legislasi. Kehendak-kehendak dalam perubahan sosial atau pembangunan dengan begitu terbaca dalam undang-undang. Keberbedaan aktor dan cara ini tentu berpengaruh terhadap sifat perubahan. Pada sociological jurisprudence, perubahan itu relatif bersifat dinamis, sekalipun hakim dalam common law mesti mempertimbangkan putusan sebelumnya; ${ }^{48}$ sedangkan dalam hukum pembangunan, karena dituangkan dalam produk legislasi, perubahan itu relatif menjadi bersifat statis dan kaku, karena berubah lagi menunggu proses legislasi yang tentu saja tidak sederhana dari segi waktu. ${ }^{49}$

Dari uraian keterhubungan hukum pembangunan dengan aliran-aliran pemikiran hukum yang disinggung Mochtar, terlihat bahwa hukum pembangunan memiliki keterkaitan dengan aliranaliran tersebut dalam sebagian aspek saja, sementara pada aspek yang lainnya justru berbeda dan bahkan bertolak belakang. Hukum pembangunan terkait dengan legisme dalam hal rupa hukum yang harus tertulis dan keberlakuannya yang universal dalam wilayah hukum; namun berbeda dalam soal hukum kebiasaan apakah diberi tempat atau tidak. Hukum pembangunan terkait dengan aliran sejarah

48 Sifat perubahan hukum yang dinamis dalam common law sebenarnya bisa dipertanyakan juga. Pada saat mulai berkembang, kemungkinan besar common law memang sistem hukum yang sangat luwes atau dinamis. Namun begitu, ia segera menjadi kaku karena prinsip stare decicis (preseden-preseden harus dihormati) dan pengenalan sistem "bentuk-bentuk tindakan" yang juga disebut writs. Lihat: Michael Bogdan, Pengantar Perbandingan Sistem Hukum, terj. oleh Derta Sri Widowatie (Bandung: Nusa Media, 2010), hlm. 127.

49 Lihat juga Shidarta, "Posisi Pemikiran Teori Hukum Pembangunan", hlm. 60. 
hukum dalam hal hukum sebagai kaidah sosial tidak bisa melepaskan diri dari nilai yang berlaku pada suatu masyarakat; tapi berbeda dalam hal bentuk hukumnya seperti apa. Hukum pembangunan terkait dengan realisme hukum yang sama-sama menekankan fungsi hukum pada kemanfaatan dan kepentingan sosial; namun berbeda tentang siapa dan bagaimana menjalankan fungsi demikian. Kondisi ini serupa dalam kaitan hukum pembangunan dengan sociological jurisprudence, yang memiliki kesamaan dalam memfungsikan hukum tetapi berbeda mengenai aktor dan cara menyelenggarakan fungsi tersebut.

Keadaan demikian disebut Shidarta menjadikan pemikiran Mochtar akan cukup sulit untuk ditempatkan secara pas dalam konstelasi aliran-aliran pemikiran hukum klasikal. Penyebutan Mochtar terhadap berbagai aliran-aliran pemikiran hukum seperti hukum kodrat, positivisme hukum, mazhab sejarah, sociological jurisprudence, dan realisme hukum, dilakukan secara sporadis untuk mendukung pernyataan dalam konteks tertentu. Relatif tidak ada upaya sungguh-sungguh dari Mochtar untuk membongkar pondasi dari pemikiran tokoh-tokoh dan aliran-aliran tersebut untuk dipakai dalam menyusun konsepsi hukumnya. Namun demikian, Shidarta juga mengakui, dari berbagai aliran tersebut, konsep hukum pembangunan memang mendekati sociological jurisprudence. ${ }^{50}$

Sekarang, bagaimanakah hukum pembangunan ditelaah dari sudut praksis dalam artian praktik hukum? Sebagaimana disebutkan sebelumnya, hukum pembangunan dari Mochtar Kusuma-atmadja bermula dari kegelisahannya tentang peranan hukum yang menunjukkan kelesuan (malaise) dalam pembangunan. Keadaan ini yang lalu mendorong Mochtar untuk merefleksikan kembali apa itu hukum beserta tujuan dan fungsinya, dan bagaimana ia bekerja di masyarakat. Latar belakang pemikiran demikian memberitahu bahwa hukum pembangunan Mochtar sangat dekat dengan praktik hukum, terutama dalam kaitannya dengan pembangunan hukum di Indonesia. Tinjauan sudut praksis di sini akan menyoroti bagaimana

50 Shidarta, "Posisi Pemikiran Teori Hukum Pembangunan”, hlm. $70 \& 76$. 
bekerjanya hukum dalam mengarahkan pembangunan.

Pertama, Mochtar mendorong dilakukannya pembaruan hukum terutama pada bidang-bidang yang dianggap netral dari segi kultur, keagamaan, dan sistem sosial, dan menangguhkan atau membiarkan untuk yang tidak netral. Pilihan demikian, yang oleh Sunaryati Hartono disebut sebagai "unifikasi dan kodifikasi parsial", ${ }^{51}$ jelas sekali menunjukkan pemikiran Sang Tokoh bahwa ada hukum yang netral dan yang tidak netral dari segi kultur, keagamaan, dan sistem sosial. Padahal, dengan menyebut hukum sebagai bagian dari kaidah sosial, sesungguhnya tercermin di sana hukum itu lekat sekali dengan kehidupan atau sistem sosial suatu masyarakat, termasuk segi kultur dan keagamaannya. ${ }^{52}$

Bidang hukum perseroan, kontrak, dan lalu lintas yang dicontohkan Mochtar dalam berbagai karyanya, ${ }^{53}$ seberapa pun kecil kadarnya tentu juga memiliki keterkaitan dengan kultur, keagamaan, dan sistem sosial. Muncul dan berkembangnya badan usaha syariah, keluarnya fatwa ulama terkait bunga dalam perjanjian pinjam meminjam, ${ }^{54}$ "polisi tidur" (speed trap), ${ }^{55}$ dan berboncengan dengan yang bukan muhrim, ${ }^{56}$ menunjukkan bidang hukum perseroan, kontrak, dan lalu lintas juga memiliki keterkaitan dengan kebudayaan dan keagamaan, betapapun kecil atau sedikit kadarnya.

Kedua, secara praksis, hukum pembangunan belum memberi kriteria yang jelas terkait perubahan sosial atau pembangunan yang perlu didukung dengan bersaranakan hukum. Hal ini penting kare-

51 Sunaryati Hartono, Bhinneka Tunggal Ika Sebagai Asas Hukum bagi Pembangunan Hukum Nasional (Bandung: Citra Aditya Bakti, 2006), hlm. 24-25.

52 Dalam tulisan Shidarta ("Posisi Pemikiran Teori Hukum Pembangunan", hlm. 51), dengan mengutip dan menelusuri pemikiran Northrop yang juga sering disebut oleh Mochtar, diuraikan bahwa semua bidang hukum sesungguhnya tidak ada yang netral.

53 Kusuma-atmadja, Hukum, Masyarakat, dan Pembangunan Nasional, hlm. 14.

54 Majelis Ulama Indonesia, Fatwa Nomor 1 Tahun 2004 tentang Bunga (Interest/Fa'idah).

55 http://mui-samarinda.blogspot.com, "Polisi Tidur (Speed Trap) Wilayah Kota Samarinda”, 25/2/2013, diakses 10/10/2018.

56 Lihat H.B. Syafuri, "Epistemologi Hukum Fatwa MUI Kabupaten Lebak tentang Berboncengan dengan Selain Muhrim”, Ahkam: Jurnal Ilmu Syariah, 16, 2 (2016), hlm. 213-222. 
na kehidupan masyarakat di manapun dan kapanpun pada dasarnya selalu ditandai dengan perubahan, yang berarti memperlihatkan ada pembangunan. ${ }^{57}$ Ketidakjelasan kriteria ini menyebabkan hukum pembangunan dengan mudah bisa digunakan dan dimanfaatkan untuk membenarkan secara hukum atas tindakan apa pun dari penguasa sepanjang mengatasnamakan pembangunan. Ia, hukum pembangunan, rentan dipakai sebagai dasar pemikiran atau konsideran dalam peraturan atau putusan hukum, ${ }^{58}$ untuk membenarkan peraturan atau putusan hukum yang dibuat dalam rangka mendukung dan memperlancar pembangunan. Padahal, dengan memahami karakteristik peraturan dan putusan hukum yang bisa responsif atau ortodoks, yang dipengaruhi oleh konfigurasi politik yang sedang berlangsung apakah demokratis atau otoriter, ${ }^{59}$ maka (peraturan dan putusan) hukum akan sangat rentan dijadikan sebagai instrumen untuk membenarkan tindakan yang diambil dan dipilih oleh penguasa.

Hukum pembangunan, dengan demikian, bisa saja terjebak pada simpulan lain di luar simpulan utama yaitu mengarahkan pembangunan, ialah mengabdi pada pembangunan atau kekuasaan. Pada

57 Secara teoretis, kegiatan pembangunan tersebut ada yang dilandasi oleh keinginan untuk mengikuti dan menyeragamkan perkembangan yang dicapai oleh negara-negara (Barat) yang sudah maju terlebih dahulu (dikenali dengan teori modernisasi), ada juga yang didorong oleh kehendak mengurangi keterkaitan dan ketergantungan negara-negara pinggiran terhadap negara sentral (teori dependensi), dan juga ada yang disemangati oleh hasrat mewujudkan tata dunia yang berkeadilan ekonomi dan politik atau dunia yang demokratis dan egalitarian (teori sistem dunia). Lihat: Suwarsono dan Alvin Y. So, Perubahan Sosial dan Pembangunan (Jakarta: LP3ES, cetakan kelima, 2013).

58 Hikmahanto Juwana, "Politik Hukum UU Bidang Ekonomi di Indonesia", Jurnal Hukum Bisnis, 23, 2 (2004), hlm. 52-65, menyebutkan, alasan "pembangunan nasional" hampir dijumpai dalam semua konsideran UU bidang ekonomi yang dibentuk setelah tahun 1980-an. Sebelumnya, pada tahun 1950 hingga permulaan tahun 1980-an, penyebutan pemberlakuan UU bidang ekonomi karena pembangunan nasional hanya dilakukan apabila ada keterkaitan yang erat dengan apa yang hendak diatur, semisal UU Penanaman Modal Asing.

59 Lihat: Moh. Mahfud MD, Politik Hukum di Indonesia (Jakarta: Pustaka LP3ES Indonesia, cetakan ketiga, 2006), hlm. 355; Daniel S. Lev, Hukum dan Politik di Indonesia: Kesinambungan dan Perubahan, terj. Nirwono dan AE Priyono (Jakarta: Pustaka LP3ES, cetakan ketiga, 2013), hlm. 389-390. 
simpulan lain ini, yang tentu saja tidak diharapkan, hukum berarti harus mengikuti kehendak dan hajat penguasa dan pembangunan, sekalipun dari pembangunan itu bisa menimbulkan berbagai persoalan. Mochtar memang berulangkali menegaskan bahwa penguasa dan kekuasaan harus tunduk pada batas-batas yang ditentukan oleh hukum. Namun, dengan determinasi politik yang sangat kuat termasuk terhadap hukum, maka fungsionalisasi hukum akan mengarahkan pembangunan atau justru menjadi instrumen untuk mengikuti dan mengabdi pada kekuasaan dan pembangunan sangat bergantung pada konstelasi politik yang sedang berlangsung.

Dalam praktiknya memang ada kegiatan pembangunan yang bisa diperdebatkan apakah mendorong perubahan sosial yang lebih baik ataukah lebih disebabkan memenuhi kehendak penguasa. ${ }^{60} \mathrm{Na}$ mun, karena kegiatan-kegiatan tersebut mengatasnamakan pembangunan dan dijustifikasi dengan instrumen hukum, maka ia berlangsung secara "teratur dan tertib". Begitu juga, ada agenda-agenda pembangunan yang sudah berlangsung dan instrumen hukumnya diadakan menyusul kemudian, yang tampak di situ hukum dipaksa memenuhi hasrat penguasa atau pembangunan.

Barangkali ketiadaan kriteria itu yang menjadi persoalan dalam hukum pembangunan saat ini, yang bisa saja menghasilkan kesimpulan yang berbeda dan bahkan bertolak belakang: mengarahkan pembangunan atau mengabdi pada pembangunan. Karena itu, menurut Shidarta, agar konsisten dengan ide hukum untuk mengarahkan pembangunan, hukum pembangunan mensyaratkan adanya iklim politik yang sehat, yang mampu memberi ruang diskursus publik yang leluasa dan cukup bernas untuk ikut mengoreksi kualitas hukum (undang-undang) yang dibentuk penguasa. Tanpa syarat ini, ia akan mudah terjerat dalam lingkaran permainan kekuasaan yang merugikan masyarakat luas. ${ }^{61}$

60 Dalam perkembangan terakhir, kegiatan reklamasi di wilayah perairan atau lautan dan pembangunan pabrik semen di wilayah pegunungan, merupakan contoh yang sangat bisa diperdebatkan apakah di sana hukum berfungsi mengarahkan pembangunan atau mengabdi pada pembangunan.

61 Shidarta, "Posisi Pemikiran Teori Hukum Pembangunan", hlm. 75-76. Demikian pula disebut Bernard Arief Sidharta, tanpa iklim politik yang 
Meski demikian, harus diakui bahwa hukum pembangunan telah berjasa penting dalam mendorong fungsionalisasi hukum untuk perubahan-perubahan yang lebih baik, tidak sebatas bertahan dalam status quo. Hukum pembangunan juga telah berjasa dalam mendorong penstudi hukum untuk memiliki keterampilan berhukum, karena kehidupan masyarakat kekinian yang semakin kompleks memang menghendaki kemampuan sarjana hukum yang terampil layaknya tukang, sekalipun hal ini juga mengundang kritik. ${ }^{62}$ Karena kehidupan masyarakat itu selalu berubah, yang berarti apa yang disebut dengan pembangunan itu berlangsung terus-menerus, maka konsep hukum pembangunan terutama terkait fungsionalisasi hukum tentu akan langgeng alias relevan dalam waktu yang lama. Tugas pentsudi hukum berikutnya untuk mengawal dan mengembangkannya, agar kriteria-kriteria yang belum ada atau masih kabur dapat dibuat dan diperjelas. ${ }^{63}$

sehat, maka fungsi hukum sebagai a tool of social engineering dalam arti sarana untuk mendorong, mengarahkan dan menganalisasi perubahan sosial ke tatanan masyarakat yang lebih baik secara teratur dan adil, mungkin saja akan diadaptasi dan didegradasi menjadi sekadar sarana untuk mencapai tujuan dan memperoleh kemenangan belaka, terlepas dari salah atau benar, adil atau tidak, serta sah atau tidak. Keadaan ini sudah terlihat dalam masa pemerintahan (Indonesia) yang represif, di mana tatanan hukum justru membuka peluang yang cukup besar bagi terjadinya korupsi, kolusi, manipulasi, penyalahgunaan kewenangan/kekuasaan, praktik mafia peradilan, serta pengesampingan asas-asas hukum dan asas-asas perundang-undangan yang fundamental. Bernard Arief Sidharta, Refleksi tentang Struktur Ilmu Hukum: Sebuah Penelitian tentang Fundasi Kefilsafatan dan Sifat Keilmuan Ilmu Hukum Sebagai Landasan Pengembangan Ilmu Hukum Nasional Indonesia (Bandung: Mandar Maju, cetakan kedua, 2000), hlm. 73.

62 Baca, misalnya, Satjipto Rahardjo, Pendidikan Hukum Sebagai Pendidikan Manusia (Yogyakarta: Genta Publishing, 2009).

63 Penambahan syarat "iklim politik yang sehat" yang diberikan Shidarta dan Bernard Arief Sidharta di atas (lihat catatan kaki nomor 61), pada dasarnya adalah bagian dari upaya memperjelas kriteria tertentu yang masih kabur dalam hukum pembangunan. Sedangkan menurut Al. Andang Listya Binawan, yang perlu dilakukan untuk "sementara" ialah menjadikan the Bill of Rights (ketiga "induk” hukum hak asasi manusia internasional yang terdiri dari the Universal Declaration of Human Rights [UDHR], the International Covenant on Civil and Political Rights [ICCPR], dan the International Covenant on Economic, Social, and Cultural Rights [ICESCR]) sebagai acuan minimal atas kontrol kekuasaan dan sekaligus jaminan hukum terhadap hak-hak 


\section{E. Kesimpulan}

Ulasan tokoh Mochtar Kusuma-atmadja dan pemikirannya hukum pembangunan dalam artikel ini menyimpulkan, pertama, hukum pembangunan merupakan reaksi dari kegelisahan Sang Tokoh terkait peranan hukum yang menunjukkan kelesuan (malaise) dalam pembangunan. Agar punya kontribusi dalam pembangunan yang berlangsung, maka hukum tidak cukup difungsikan untuk menjaga ketertiban kehidupan masyarakat, suatu fungsi konservatif; hukum harus pula diberdayakan untuk mengarahkan perubahan dan pembangunan supaya berlangsung secara teratur dan tertib. Kedua, untuk mendukung fungsionalisasi hukum dalam pembangunan, hukum pembangunan mendorong perlu dilakukannya pembinaan hukum nasional yang meliputi antara lain pembaruan hukum dan pendidikan hukum. Pada soal pembaruan hukum, hukum pembangunan memprioritaskan pembentukan atau perubahan hukum pada kebutuhan hukum yang mendesak dan yang "netral" dari segi kultur, keagamaan dan sistem sosial, sembari menangguhkan dan membiarkan hukum yang sudah ada sekalipun plural karena "tidak netral”. Sedangkan pada soal pendidikan hukum, hukum pembangunan mendorong fakultas hukum melakukan reorientasi tujuan pendidikan hukum, pelaksanaan kurikulum minimum, pembinaan tenaga pengajar, dan pendidikan hukum klinis, yang ditujukan agar mahasiswa setelah lulus memiliki kompetensi profesional di bidang hukum.

Ketiga, secara akademis, ditelisik dari aliran-aliran hukum yang selama ini dikenali, hukum pembangunan lebih dekat kepada sociological jurisprudence, karena sama-sama mendorong fungsionalisasi hukum sebagai sarana pembaruan masyarakat atau pembangunan.

dan kebebasan dasar manusia dan warganegara, sehingga rekayasa sosial yang diupayakan dengan bersaranakan hukum memang sungguh demi kemaslahatan umum dan bukan demi kepentingan diri atau kelompok tertentu (Al. Andang Listya Binawan, "Menimbang Ulang Hukum Sebagai Sarana Rekayasa Sosial", dalam Dialektika Pembaruan Sistem Hukum Indonesia, ed. Dinal Fedrian, dkk. [Jakarta: Sekretariat Jenderal Komisi Yudisial Republik Indonesia], hlm. 248). 
Namun demikian, di antara keduanya sesungguhnya berbeda dalam soal aktor yang berperan dan cara bekerjanya hukum. Pada sociological jurisprudence, aktor perubahan itu adalah hakim melalui proses yudisial, sementara pada hukum pembangunan dilakukan oleh pembentuk undang-undang melalui proses legislasi. Keempat, hukum pembangunan secara praksis urgen agar agenda-agenda pembangunan berlangsung secara tertib. Karena kehidupan masyarakat selalu ditandai oleh perubahan-perubahan yang menunjukkan adanya proses pembangunan, maka gagasan hukum pembangunan terutama terkait fungsionalisasi hukum jelas akan relevan dalam setiap masa. Namun demikian, sekaligus sebagai simpulan kelima, ketiadaan kriteria perubahan atau pembangunan seperti apa yang perlu didukung dengan bersaranakan hukum, sementara di sisi lain karakter produk hukum itu dipengaruhi oleh konstelasi politik yang tengah berlangsung, menyebabkan proyeksi hukum pembangunan bisa dan mudah terjebak pada kehendak-kehendak pembangunan atau kekuasaan, dan bukan semata-mata mengarahkan pembangunan.

\section{Daftar Pustaka}

\section{Artikel/Buku/Laporan}

Aulia, M. Zulfa. "Hukum Progresif dari Satjipto Rahardjo: Riwayat, Urgensi, dan Relevansi”. Undang: Jurnal Hukum, 1, 1 (2018): 159185. DOI: 10.22437 / ujh.1.1.159-185

Binawan, Al. Andang Listya. "Menimbang Ulang Hukum Sebagai Sarana Rekayasa Sosial”. Dalam Dialektika Pembaruan Sistem Hukum Indonesia, diedit oleh Dinal Fedrian, dkk., 230-252. Jakarta:

Sekretariat Jenderal Komisi Yudisial Republik Indonesia.

Bogdan, Michael. Pengantar Perbandingan Sistem Hukum. Terjemah oleh Derta Sri Widowatie. Bandung: Nusa Media, 2010.

Hartono, Sunaryati. Bhinneka Tunggal Ika Sebagai Asas Hukum bagi Pembangunan Hukum Nasional. Bandung: Citra Aditya Bakti, 2006.

Huijbers, Theo. Filsafat Hukum dalam Lintasan Sejarah. Yogyakarta:

Penerbit Kanisius, 1982. 
Http://mui-samarinda.blogspot.com. "Polisi Tidur (Speed Trap) Wilayah Kota Samarinda”, 25/2/2013. Diakses 10/10/2018.

Juwana, Hikmahanto. "Politik Hukum UU Bidang Ekonomi di Indonesia”. Jurnal Hukum Bisnis, 23, 2 (2004): 52-65.

Kusuma-atmadja, Mochtar. Fungsi dan Perkembangan Hukum dalam Pembangunan Nasional. Bandung: Lembaga Penelitian Hukum dan Kriminologi Fakultas Hukum Universitas Padjadjaran \& Penerbit Binacipta, tanpa tahun.

Kusuma-atmadja, Mochtar. Hukum, Masyarakat, dan Pembinaan Hukum Nasional. Bandung: Lembaga Penelitian Hukum dan Kriminologi Fakultas Hukum Universitas Padjadjaran \& Penerbit Binacipta, 1976.

Kusuma-atmadja, Mochtar. Konsep-konsep Hukum dalam Pembangunan; Kumpulan Karya Tulis, diedit oleh Otje Salman dan Eddy Damian. Bandung: Pusat Studi Wawasan Nusantara, Hukum dan Pembangunan bekerjasama dengan Penerbit PT. Alumni, cetakan kedua, 2006.

Kusuma-atmadja, Mochtar. Pembaharuan Pendidikan Hukum dan Pembinaan Profesi. Bandung: Lembaga Penelitian Hukum dan Kriminologi Fakultas Hukum Universitas Padjadjaran \& Penerbit Binacipta, 1975.

Kusuma-atmadja, Mochtar. Pembinaan Hukum dalam Rangka Pembangunan Nasional. Bandung: Lembaga Penelitian Hukum dan Kriminologi Fakultas Hukum Universitas Padjadjaran \& Penerbit Binacipta, 1975.

Kusuma-atmadja, Mochtar. Pengaturan Hukum Masalah Lingkungan Hidup Manusia: Beberapa Pikiran dan Saran. Bandung: Lembaga Penelitian Hukum dan Kriminologi Fakultas Hukum Universitas Padjadjaran \& Penerbit Binacipta, tanpa tahun.

Kusuma-atmadja, Mochtar dan Bernard Arief Sidharta. Pengantar Ilmu Hukum; Suatu Pengantar Pertama Ruang Lingkup Berlakunya Ilmu Hukum. Bandung: Alumni, cetakan keempat, 2016.

Latipulhayat, Atip. "Friedrich Karl von Savigny". Padjadjaran: Jurnal Ilmu Hukum, 2, 1 (2015): 197-208.

Lev, Daniel S. Hukum dan Politik di Indonesia: Kesinambungan dan Per- 
ubahan. Terjemah oleh Nirwono dan AE Priyono. Jakarta: Pustaka LP3ES, cetakan ketiga, 2013.

Mahfud MD, Moh. Politik Hukum di Indonesia. Jakarta: Pustaka LP3ES Indonesia, cetakan ketiga, 2006.

Manullang, E. Fernando M. Legisme, Legalitas dan Kepastian Hukum. Jakarta: Kencana, 2016.

Pane, Nina. Rekam Jejak Kebangsaan Mochtar Kusuma-atmadja. Jakarta: Penerbit Buku Kompas, 2015.

Rahardjo, Satjipto. Hukum dan Perubahan Sosial. Yogyakarta: Genta Publishing, 2009.

Rahardjo, Satjipto. Pendidikan Hukum Sebagai Pendidikan Manusia. Yogyakarta: Genta Publishing, 2009.

Rasjidi, Lili. "Fase Kedua Perjalanan Teori Hukum Pembangunan". Dalam Mochtar Kusuma-atmadja dan Teori Hukum Pembangunan: Eksistensi dan Implikasi, diedit oleh Shidarta, 121-131. Jakarta: Epistema Institut \& Huma, 2012.

Rasjidi, Lili. "Introduksi”. Dalam Filsafat Hukum: Mazhab dan Refleksinya, diedit oleh Lili Rasjidi dan B. Arief Sidharta, 1-12. Bandung: Remadja Karya, 1989.

Reksodiputro, Mardjono. "Mochtar Kusuma-atmadja Sebagai Pemikir dan Penggagas Modernisasi Pendidikan Hukum di Indonesia”. Dalam Mochtar Kusuma-atmadja: Pendidik \& Negarawan, diedit oleh Mieke Komar, Etty R. Agoes, dan Eddy Damian, 713732. Bandung: Alumni, 1999.

Shidarta. "Posisi Pemikiran Teori Hukum Pembangunan dalam Konfigurasi Aliran Pemikiran Hukum (Sebuah Diagnosis Awal)". Dalam Mochtar Kusuma-atmadja dan Teori Hukum Pembangunan: Eksistensi dan Implikasi, diedit oleh Shidarta, 9-79. Jakarta: Epistema Institut \& Huma, 2012.

Sidharta, Bernard Arief. Refleksi tentang Struktur Ilmu Hukum: Sebuah Penelitian tentang Fundasi Kefilsafatan dan Sifat Keilmuan Ilmu Hukum Sebagai Landasan Pengembangan Ilmu Hukum Nasional Indonesia. Bandung: Mandar Maju, cetakan kedua, 2000.

Sianturi, Togi R. "Apakah Ada Suatu Mazhab Unpad dalam Filsafat Hukum?”. Dalam Filsafat Hukum: Mazhab dan Refleksinya, diedit 
oleh Lili Rasjidi dan B. Arief Sidharta, 120-127. Bandung: Remadja Karya, 1989.

Soekito, Wiratmo. "Kaum Intelektual dan Teknokrat: Mencari Definisi”. Dalam Cendekiawan dan Politik, diedit oleh Aswab Mahasin dan Ismed Natsir, vii-xxvi. Jakarta: LP3ES, cetakan kedua, 1984. Sumardjo, Jakob. "Biografi Prof. Dr. Mochtar Kusuma-atmadja, S.H., LL.M.” Dalam Mochtar Kusuma-atmadja: Pendidik \& Negarawan, diedit oleh Mieke Komar, Etty R. Agoes, dan Eddy Damian. Bandung: Alumni, 1999.

Suwarsono dan Alvin Y. So. Perubahan Sosial dan Pembangunan. Jakarta: LP3ES, cetakan kelima, 2013.

Syafuri, H.B. "Epistemologi Hukum Fatwa MUI Kabupaten Lebak tentang Berboncengan dengan Selain Muhrim”. Ahkam: Jurnal Ilmu Syariah, 16, 2 (2016): 213-222. DOI: 10.15408/ajis. v16i2.4451

Tanya, Bernard L., Yoan N. Simanjuntak, dan Markus Y. Hage. Teori Hukum: Strategi Tertib Manusia Lintas Ruang dan Generasi. Yogyakarta: Genta Publishing, cetakan keempat, 2013.

Wignjosoebroto, Soetandyo. "Mochtar Kusuma-atmadja: Manusia yang Pernah Saya Kenal dan Pemikirannya (Sebuah Pengantar Ringkas)". Dalam Mochtar Kusuma-atmadja dan Teori Hukum Pembangunan: Eksistensi dan Implikasi, diedit oleh Shidarta, viixxiv. Jakarta: Epistema Institut \& Huma, 2012.

Wignjosoebroto, Soetandyo. Pergeseran Paradigma dalam Kajian-kajian Sosial dan Hukum. Malang: Setara Press, 2013. 